\author{
Maryna CHYZHEVSKA \\ Poltava University of Economics and Trade, Ukraine \\ Vladyslav CHYZHEVSKY I \\ Poltava State Agrarian Academy, Ukraine
}

\title{
Social Politics of Civil Society
}

\section{Polityka społeczna społeczeństwa obywatelskiego}

\section{- Abstrakt •}

Artykuł prezentuje spojrzenie z punktu widzenia wielu kultur na cechy dynamiki zmian w rozumieniu pojęć takich jak „społeczeństwo”, „polityka” i „stan”. Niniejsza praca podejmuje temat złożoności i wielopłaszczyznowości indywidualnej świadomości politycznej. Autorzy rozwijają ten watek w oparciu o dynamikę historyczną i proponują by rozważać proces transformacji antycznego państwa-miasta i wynikających z niej relacji politycznych w kontekście współczesnego państwa wraz z jego złożonym systemem politycznym. W artykule podkreślono, że trudność w rozumieniu charakteru i roli polityki społecznej wynika również z języka oraz różnic etymologicznych i konceptualnych.

Słowa kluczowe: polityka społeczna, społeczność, społeczeństwo, stan, obywatele, samoorganizacja

\section{- Abstract •}

This paper presents a cross-cultural overview of the features of the dynamics of the perception of the concepts of "society", "politics", and "state". The work raises the issue of complex and multifaceted individual consciousness of understanding policy. Authors formulate this aspect from the perspective of historical dynamics and propose to explore the process of transformation of the ancient city-state and flowing therefrom political relations in the modern state with its complex political system. It was stressed that the problem of understanding the nature and role of social policy is complicated by language as well as etymological and conceptual differences.

Keywords: social policy, community, society, state, citizens, self-organization

The basic concept in the preparation of this work was to unite the efforts of different scientific disciplines representatives to solve one of the three fundamental areas of scientific knowledge problems, which can be drawn up on presence in the subject and object of study relationships between individuals in communities of 
all sizes - from the family to global socium. In other words, everything that is accepted to interpret in the academic rhetoric as social sciences. Given the various methodological difficulties, which are inherent to the unification of knowledge on this principle (Сироткин, 2011, p. 74), and also constantly arising cross-cultural collisions in interpretation of various academic categories that are the result of interstate isolation of scientific knowledge systems formation processes to preserve the interest of a wide range of experts it was suggested to use at least capacious phrase - social policy. The reality of processes united by the term "globalization" in the world is increasingly becoming part of people's consciousness, being expressed in the sense of belonging to the largest human community - the world socium, evolving from tribal ideas of the social world through the ethnic group, the ancient city and to the modern understanding of citizenship, outlined by the boundaries of each country. Communities of all sizes are converted into full participants of the global resources sharing. The modern society is becoming the society gradually embracing the whole inhabited world into one giant social system (Иуман, 2000, p. 16). Understanding the scale of a problem allows the researcher to abstract from detection of social processes regularities in the subsystems only that in future should create the ground for general formal description of the world-system (Luhmann, 1980). If to omit the idea of Dante Alighieri on the establishment of a worldwide empire of humanity (Алигьери, 1999), inherently the concept of universal legal civil society - state (civitas gentium), proposed by Immanuel Kant in 1795 , became the first research dedicated to solving the problem of scale in social sciences. "Only in such a society the highest goal of Nature can be achieved: the development of all its potentialities inherent in humanity; at the same time nature wants this purpose, like all the other implemented by itself" (Кант, 1966, p. 12). "The desire for self-preservation - this is the main motive, which is subject to each individually and altogether ... In accordance with the mind in the relationship of states between themselves there can be no other way to come out free from the law of state of constant war, other than repudiate, similar to individuals, from its wild (not based on law) freedom, to adapt to public compulsory law and thus form (obviously constantly extending) the people's state, which finally will cover all the nations of the earth" (Höffe, 2011). Hence it follows that the process, ensuring coordination of a variety of internal interactions in each of its own unique subsystems, is nothing else than an aspiration to self preservation of the society through the maintenance of the order in the system. The implementation of regulatory interests of each individual in the social system takes place by means of a specific mechanism, concentrating the interests of society in relation to the life of individuals, constituting this society, what in essence is social policy. 
The etymology and the concept of "society" have their roots in Latin in the noun "socius" - ally, fellow traveler, which is used in the description of positive interaction between individuals. In the process of life complication, slowly filling with diverse semantic contexts, allies gradually create a complex pattern of civilized (civil) society - "societas civilis", fastened by threads of interests stretching from Roman collegiums' microcosm "collegii societatis".

The definition of "sociality" as a concept, identical to society in the natural conditions of human life, was quite clearly formulated by John Locke in Two treatises of government (1690)1. Socium and society are identical also in the work of Jean-Jacques Rousseau Du Contrat social; ou, Principes du droit politique (Of the social contract or principles of political right, 1762). Over time, the notation of society as a "social" becomes regular, acquiring routine nature, overgrowing with different definitions and derivative interpretations in the process of use. Thus, for example, in 1834 Pierre Leroux in his article De l'individualisme et du socialism, published in Revue Encyclopédique, first uses the term "socialism", describing it as the opposite to the concept of liberal doctrine of individualism and free competition $^{2}$. In Russian, Ukrainian, and Belorussian the language emergence of "social" can be traced in the $19^{\text {th }}$ century by borrowing from Western Europe and from the outset it is used in parallel with an understanding of the society (the world) as the integrity. Until recently, the post-Soviet understanding of "social" was quite vague and largely associated with socialism as a way to build social relations opposed to capitalism.

Still more complex and multifaceted for the individual consciousness is the understanding of politics. The problem of meaning filling, determination of everything we commonly call the "political" always existed and remained relevant to all peoples and nationalities. It is generally accepted that East Slavic languages have borrowed this concept from French where "polytique" through Latin mediation dates back to the Greek "polytike", produced by "polis" - town, state. The earliest scientific works devoted to politics we find in ancient antiquity. In Politics ( "that is about polis" or in a broader sense as a "philosophy of human affairs", where the sense of bringing people together is explained by the desire to achieve the high-

1 The original name of work - Two Treatises of Government: In the Former, The False Principles, and Foundation of Sir Robert Filmer, And His Followers, are Detected and Overthrown. The Latter is an Essay concerning The True Original, Extent, and End of Civil Government.

2 "Encyclopédie nouvelle ou Dictionnaire philosophique, scientifique littéraire et industriel, offrant le tableau des connaissances humaines au dix-neuvième siècle par une société de savants et de littérateurs" (1834-1841). 


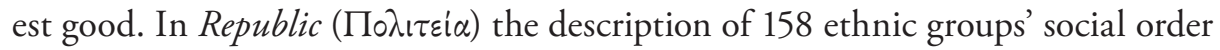
(prior to our time only the Athenian remained) is offered, considering the latter as the community, outside the polis and is not able to make it. The work Пo $1 \tau \varepsilon i \alpha$, written by Aristotle, who was mentored by Plato, is not interpreted as clearly. It is known that for the first time this work appeared in Europe through Arab sources, in which it has already been arranged under the title Republica - Republic. Obviously, for this same reason, the Russian-speaking reader got the work under the name State. It is believed that from the French (a known written source dates back to the year 1430) the concept of "political" migrated into English, where the source dates back to 1520 (Liberman, 2009). In modern English language the three main semantic units formed from the ancient "polis" are "politics", "polity", and "policy".

"Politics" - is used about or with regard to citizenship and is the process by means of which groups of people take collective decisions. The word is commonly used in relation to the art of public affairs in the government, Parliament, local self-government extending also to special interest groups - religious, academic, and corporate layers of society. As a concept it covers all social relations connected by the power by means of the state.

"Polity" - society with control attributes inherent to statehood, government, public, and political territorial unit organized in a certain way.

"Policy" - the process of making and planning alternative solutions, rules, and methods of interaction usually in organizations in order to achieve rational results in the foreseeable future. It may also be seen as a statement of intent.

In the East Slavic group of languages such differentiation of the aforementioned concept does not exist, its application in the process of linguistic activity is made dependent on the context of the semantic load in each particular situation. But the prefix "poli-" is widely used in word formation, which indicates a plurality or a large amount of something or extreme manifestation of any attribute. Within our research it is particularly interesting to follow the concept "police, polizei, policía" transformation metamorphosis in Western variant as the embodiment of state-society, designed to reduce the differences in civil cases and the concept of "police" in the East Slavic language group as a system of government services and bodies established for the protection of the public order. However, without a preliminary study of the social processes that led to the modern understanding of the "statehood", any conclusions concerning the problems outlined above will be fragmented. If we formulate the question from the perspective of historical trends, it turns out that we need to explore the process of turning an ancient city-state and political relations occurring in it into a modern state with its complex political sys- 
tem. Such an approach maybe will also ease clarifying the difficulties arising from the interpretation of the previously mentioned work of Plato called State.

In the English and most European languages, Russian word "state" corresponds to "state" (stato - in Italian, estado - in Spanish, état - in French, Staat in German). Ultimately, these linguistic units are derivatives from the Latin word "status", which means "state" or "status" (Liberman, 2009). In Ukrainian, Belarusian, Bulgarian, Bosnian, Macedonian, Serbian, Slovenian, and Croatian various definitions are used as derivatives from the word "power". In Polish language the word "państwo" corresponds to Russian "state" that according to the sounding is identical to the lexical unit "panstvo" and corresponds to the semantic load, indicating the number of persons possessing a certain status.

Hannah Arendt believes that the word "state" in European languages as a separate notion took shape only at the turn of $16^{\text {th }}$ century to describe a new form of political organization that grew out of the Renaissance. Its view is based on the fact that in antique Greek and Roman law there was no specific legal fiction a legal person, without which it is impossible to build a modern understanding of the concept of state. Therefore, along with the other documents known to us, the quote "Qui est rei publicae status?", taken from the work of Cicero De re publica should be interpreted as follows, - "What is the position in the society?". Hence "status rei publicae" - is a collection of individual statuses of independent equal citizens, interacting in a certain order, i.e. a form of government, then the combination of words "res publica" - will mean "public affair". At the same time, decent individuals "civis" - citizens under the auspices of the agreement, which have the force of law for the whole society ("concilium coetusque hominum jure sociati") act as a special social body - civitas, which is the prototype of the state (Arendt, 1958). Neither the Holy Roman Empire nor the Byzantine Empire nor other European kingdoms, consisting of innumerable set of virtually independent cities, estates, and corporations, were yet states in their essence; however, at the same time, they already had an overarching worldview underpinning. According to Niklas Luhmann, in order to justify the domination, social stratification, and personality that generalized regulatory submissions consolidated into space-religious morality emerge. Once oppositional, born by poor and oppressed periphery, inherently people's understanding of the world becomes favorable for the society as a whole. Cultural and political relationships acquire a universal nature, due to the sacred understanding of reality, including the origin and status of the Holy See. In this world, designated as "res publica christiana" the Pope was the representative of the supreme authority harmoniously arranged by the higher mind, who gave the people the sacred law of justice, by which without any doubt the 
whole of society must be guided. This peculiar monopoly on the universal knowledge is a crucial difference between the second Roman Empire and the first and especially the ancient world. Apart from all the other social interests, including business, the public discourse from "res politicae" shifts to a sacred sphere - "res ecclesiasticae" (Иуман, 2000, p. 17). Here also together with the reasons for the association and co-operation all kinds of conflicts are also shifted. For example, in his speech at the Council of Lyons, created in 1245 with the aim of overthrowing Emperor Frederick II, Pope Innocent IV solving the question of whether it is possible to excommunicate a corporation stated that any ban applies only to the soul and conscience. Therefore, this action can not be performed on abstract concepts (nomen intellectuale) and legal denominations (nomina sunt juris), that have neither soul nor conscience nor will nor consciousness (Wetterau, 1994). The existence of a peculiar spiritual monopoly in the natural order has closed a significant part of the material flows in society on the church hierarchy, which in turn contributed to its rapid growth. The situation caused gradually increasing discussions about the ineligibility of wealth accumulation by church institutions as unworthy business for the spiritual realm and being the prerogative of the society and the secular authorities. It is noteworthy that the problem of coexistence of secular and ecclesiastical authorities in the context of primary origin, respectively, of subordination, as well as in the context of the origin of the rights of individuals to liberty and public control of the latter is considered in detail by many philosophers and theologians of that distant time. The conflict that broke out in 1075 between Pope Gregory VIII and Emperor Henry IV is very often described (Амигьери, 1999; Daguet, 2007). Thus, within the sacred sphere in opposition to the Catholic Church act both contenders for the regional authorities and the various theological currents of dissidents, which conditionally may be integrated under the concept of Protestantism. The ideal of new spiritual organizations is a return to apostolic Christianity. Inherently Reformation is reflected in the replacement of hierarchical subordination by the network coordination - parishioners regain the homolographic status and the ability to choose spiritual leaders. At the same time the first Protestants we know - John Wycliffe and John Huss translated biblical texts in the then popular English and Czech languages. A considerable role in the destruction of the spiritual monopoly belongs to a number of inventions in the printing business, which entailed the spreading of literacy. Reading books and sermons on the national source of supreme authority in the church in language clear to everyone stimulated a motley audience to participate in new organizations. Attempts to save the spiritual monopolies lead to a large-scale armed conflict that resulted in mass starvation and epidemics that affected the interests of all classes' representa- 
tives. Within each community gradually emerge legitimate regional variations of Christianity, coinciding with the linguistic and cultural areas, that allows talking about the final design of such a category as the "nation", out of which national states slowly grow. The decay of "res publica christiana" distributed in time is accompanied by radical change in the understanding of everything that is relevant to the arrangement of political life. Once unifying mission degenerated into barren unification. Niccolo Machiavelli described the situation as follows: "It is not possible to provide more evidence of the religion decay, rather than an indication that the people, who is the closest to the Roman Church, being the head of our religion, is of least religious. The one who will consider the foundations of our religion and will see how different are its current customs from age-old, the original, will come to the conclusion that it is certainly close to either his death or to a painful tests. Rooted in Italy and appropriating secular power, the Roman Church has not proved to be neither as strong nor as glorious to be able to set their own tyranny over the whole of Italy and become its sovereign" (Макиавемли, 2009).

Faced with the prospect of increasing its competitive status, the elite are making intellectual efforts to develop new concepts, allowing to fasten their existence to the new reality. During the negotiations between the warring parties ${ }^{3}$ emerged the principle "cuius regio, eius religio" (the faith is of the one, to whom belongs the power), that is not only the actual approval of regional variants of Christianity, but also a perpetual transfer of the still sacred power to individuals, who previously received it only by means of the Holy See. The new Protestant concept acts as a kind of strengthening compound for the new independent monarchies. It is based on modernization of two ideas: God rules equally the spiritual (regnum Christi) and the worldly (regnum civile). People performing their worldly or professional duties, carry out a God-given vocation. All legal professions are pleasing to God. Consensus against those who disagree with the new version of the Regional Christianity was achieved. They are allowed to freely leave the territory of the kingdom, which essentially can be considered as nucleation of freedom of conscience. On the other hand, the idea allowing concentrating in one center the credentials that belong to many individuals, cities, and corporations is still needed. As a result, the findings transform into two very ordinary for us concepts: sovereignty and national or state interest.

The etymology of the word "sovereignty" dates back to the Latin "superanus", or "suprema potestas", which means "the highest authority" and to the French "soveranite" and owes its origin to the ancient concept of basileus. Aristotle in his

3 Peace of Augsburg 1555. 
Politics gave the definition to basileus as ruler, elected by the people or accepted by the people voluntarily, in contrast to the ruler - a tyrant who seized power by force. Aristotle believed that the position of basileus has very ancient origins, and it was inherited by the Athenians in the mythological times. As a separate notion that characterized the limits of the supreme authority of the king, the term "souverain" (sovereign) in 1282 was used by Philippe de Beaumanoir. This medieval lawyer created a collection of traditions (coutume), which have developed by this time in the north-eastern part of France - in the province of Bovezi and combined correspondingly entitled Coutumes de Beauvaisis (Coustumes de Beauvoisis). The collection contains the rules governing a wide variety of public relations. Its appearance is due to the fact that measures taken by Louis IX were aimed at centralizing power and thus demanded unification of the law in the northern territory under his control, where in contrast to the southern regions of France, exposed to significant influence of the Roman Empire, written law was not widely developed. De Beaumanoir devotes a separate article to the problem of sovereignty, which explains that besides the highest sovereign - king, other individuals within its territory may act as sovereign - barons, counts, and dukes (Бовези, 1961). There is also a more moderate point of view. According to it, the concept of sovereignty was first justified only in 1576 by the French jurist Jean Bodin in the treatise Les six livres de la Republique. The work is known by Russian-speaking readers under the title Six Books of the Commonwealth. It is from this work that classical definition of sovereignty as absolute and unshakable power of the monarch in a society is being widely cited (Сергунин, 2010, p. 5).

The concept of national and public interest comes from the Latin noun phrase "ratio status" - "the ratio of states". Its literal translation and interpretation in a modern interpretation has numerous variations. The concept's popularity was so great that is brought to life the birth of the "national" analogues. The French version it is "raison d'État", in German - "Staatsräson", in Italian - "ragione di stato". In English version it is "national interest", that is fully consistent with the modern concept of "national interest". A pretty impressive number of reputable scientists' works is dedicated to the above-mentioned concept. Of these the book of Giovanni Botero Della ragion di Stato, which was published in Italian in 1589, is the most famous. Usually its name is translated as "State wisdom" or "State mind". As a result of such an interpretation, there is an opportunity use a specific, relevant to today's realities context that is best illustrated by the words of Michel Foucault. "The state is governed by its inherent rational laws, which can not derive only from natural and divine laws, as also only from precepts of wisdom and prudence; state, like nature, has its own rationality, even if it is a special type of rationality" 
(Фуко, 2011). However, this idea of "ragione di stato" as of the complex concept corresponds to the realities that distant time in a bad way - by the author's worldview, in the part that concerns "state", and it is close enough to the perception of reasonableness expressed through "rationality".

It must be said about the existence of another very important feature - different ways of emergence of lexical units (and, of course, everything that is called the historical features of development) related to the state in the "Western" and "East Slavic" world still play a role in daily practice, expressed in relation of the society to its "formal structure". In Russian culture "state" and the political power, which manages the common affairs of organized society are often confused (for example: "in this state..." and "state insists on the more intense intervention into economics...”; ВАасов, 2002, p. 70). According to our assumption, intuitive ideas about the state, for example of the French-speaking population are not equal to the ideas of the Russian-speaking population. The emergence in Russian language the word "state" can be traced from the time of Moscow principality expansion under the leadership of Grand Duke Ivan III (1462-1505). While expressing its power claims to "Lord Novgorod the Great and his voluntary people" the Grand Duke said: "We, the Grand Duke, want our state, both in Moscow, and in our Motherland Novgorod the Great. There will be no chamber in our homeland Novgorod, no head of the city, but we will rule the state" (Скрынников, 1994). But, in this context the word "state" is used as derivative from the word "sovereign". On the one hand having sacred meaning that is transmitted by the expression "Lord God", on the other hand corresponding to pragmatic view of the role "head" in human anatomy conditionally transferred to the structure of society (Barnes, 1982). The following situation may serve as an example. Diarchy, which arose in the course of "collecting land", forced the "bailiff" from Novgorod "to look for the court" not in native "state", but of the sole Chief Judge - "sovereign" Ivan III. "Complainants" seeking for "grace" bypassing the existing right used the title "sovereign" instead of "Lord", indicating the advantage of Moscow's ruler before Novgorod "state", indirectly evidencing the emergence of a new relationship of subordination. It is known that shortly after the fall "Lord Novgorod the Great" Ivan III has expanded his title and became known as the Grand Duke of Moscow (Скрынников, 1994). Thus in Russian-language the concept of "statehood" encompasses the sacred meaning and dates back from the idea of centralization of power, as a common good for the country and its citizens.

Going back to "state of rationality" of Michel Foucault it is necessary to recall that "rationality" is interesting for us because of two coincidences: the similarity of views on it both in the past and in the present, and the existence of a high- 
level identity, both in western and eastern language environment. The concept of rationality is an important part of modern scientific thinking and is widely used in philosophy, economics, sociology, political science, psychology, and pedagogy. The understanding of rationality as an essential quality of a modern man amenable to improvement in the socialization process is a kind of axiom of social sciences. The sense of rationality is also inherent in every single person, expressing confidence in their ability to regulate the reality and organize the future. Let's illustrate the above-said with the expression of Bertrand Russell: "I used to think of myself as of a Rationalist; both Rationalist and I think that this - is the one who desires people to be reasonable" (1928). In the complicating modern world it is becoming more difficult for a man to make rational decisions. Many people prefer to use heuristic analysis rather than the strict application of optimization rules due to the complexity of the situation and the impossibility to calculate and to take into account the utility of each possible action. The search for the best decision is also limited by the availability of resources, knowledge, and information (Herbert, 1957).

The concept of rationality is rooted in antiquity. The basis for transition "from myth to logos", from "magic of spirit to magic of numbers" were achievements in the field of mathematics - provisions of Hipparchus planimetry, the postulates of Euclidean geometry, the theory of magnitudes' correlation of Eudoxus of Cnidus, and mathematical school of Pythagoras. The number is at the core of things, taught Pythagoras, to know the world - means to know the numbers governing it. Space is an ordered expression of a number of initial essences. Numbers are not the atoms of the universe, which make up all the things. Things are not equal to numbers, but similar to them, based on quantitative relationships of the reality. The ratio of bodies is proportional, extended world of celestial bodies obeys the laws of geometry and mathematics, the human body is beautiful and arranged according to the Polykleitos canon. The magic beauty of the "golden ration" or "golden section" law further agitated the minds of mankind throughout its history, from Leonardo da Vinci and Newton to our contemporaries, embodied in the most diverse spheres of human activity (Гриценко и Аp., 2008). In Latin in the word "ratio" - "calculation", "relation", "reason", sometimes "mind", from which actually "rationalitas" is derived - rationality as a lexical unit, the mathematical context is present immanently. It is precisely this sense that Romans laid down in the title of the treasurer of the empire - "Rationalis", which was later abolished by the emperor Diocletian, notorious as the "author" of the most ancient financial crisis (Barnes, 1982). Thomas Hobbes describes the existence of the above-mentioned relationship as follows: "The Romans called cash accounts rationes, and 
the counting operation - ratiocinatio, also those things that we in debentures and counting books call the article accounts they called nomina, i.e. titles, and hence, it seems that, they spread the word ratio on the ability of an account in all other things. The Greeks have only one word logos for speech and mind" (Гоббс, 1991).

Aristotle believed that the possession of rationality is the hallmark of men:

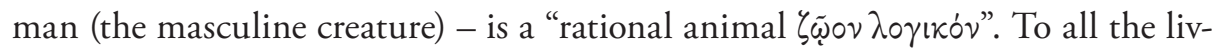
ing beings natural cognitive abilities are inherent: language, sight, smell, and in exceptional cases, rationality. Due to the fact that nature has endowed man with

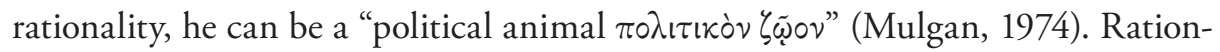
ality, along with other natural abilities such as strength, agility, courage, in the natural order "appoints" a man the responsible position of family head. Thus, man becomes a necessary and natural condition around which the basic unit of society is formed - "oinkos house, household, house and grounds". Its design due to its naturalness is unbreakable. For the same reason, the state of a woman who by virtue of ability to stand in need of protection and care always remains unchanged. The meaning of household in the representation of the ancient Greeks is fundamental. A separate science is dedicated to it - "oikovoukxós economy", which, along with other disciplines, before becoming "equal among the equal", every man is obliged to learn. The existence of polis is as natural as the existence of a household and is caused by the desire of people to live together. The innate inequality of abilities is the reason why people unite, hence it is also the difference between functions and the position of people in the society. In the very essence of things the order is rooted, by virtue of which from the moment of birth, some creatures are meant to obey, while others - to rule. The nature of every object is that its " $k \alpha \tau \dot{\alpha} \sigma \tau \alpha \sigma \eta$ condition", which is obtained at the completion of its development. One slave is different to the other slave; one master is different to the other master. How much craft work stands out above the slave labor? Craftsman, who is doing the low craft, is in a state of a limited slavery; the slave is the slave by nature, but neither the shoemaker, nor any other craftsmen are ones by nature. The philosopher draws a static picture of the human society, in which individuals are at different stages of the "social ladder", that is, they are in a certain position with respect to each other and all together simultaneously. The idea of society structure as a "condition" of citizens is displayed by ancient jurists in "Corpus juris civilis" and by means of Roman law reception it is preserved up to the present day.

The static model of society is used in the works of many researchers. Thomas Hobbes thought that the natural state (status naturalis) of individuals in the society preceded the civil status (status civilis). Under the natural state, man uses his own power at his discretion to maintain his own nature, that is, own life. In the 
civil status people agree to abandon the right to all things to the extent which is necessary in the interests of peace and self-defense and are satisfied with a degree of freedom with regard to other people, which they would allow to the other people in relation to themselves. In the absence of civil status it is always a war of all against all. According to Immanuel Kant, the condition of individuals as a part of people in relation to each other is called civil (status civilis), and their set in regard to its own members - state (civitas). By virtue of its shape as something related to the general interest of all to be in a legal state, it is called commonwealth or commonality (res publica; Кант, 1966). Thomas Hobbes defines the state as a single entity, responsible for the actions of which the great number of people made themselves responsible for, to enable this entity to use the power and the means of those in any way needed for a peaceful state and general protection (Гоббс, 1991). "State substance is a combination of the principle of family and civil status" - postulates in the Philosophy of Spirit Georg Hegel (Гегемь, 2008). There is quite an old and a fairly widespread belief that the first known to us source in which the word "State" (Italian equivalent "stato") corresponds to the modern English word "state" were the works of Niccolo Machiavelli (1469-1527; Dowdall, 1923, p. 98). However, modern scholars believe that as concept the word "stato" was synonymous with neither the Greek "polis" nor Roman "Republic", mainly because there was no ethical component in it. In other words, the word "stato", which for lack of a better word we translate as "state" or "public", due to a stronger link with a political body, suggests something similar to "power apparatus". The notion was filled with content following the development of the described object itself - national state, and still it did not materialize in most European monarchies, although the term has already begun to live its own life (Алексеева, 2011). It is known that the basis for the development of a new civilization, the common heritage of culture of all the peoples of the West were three major achievements of the Roman civilization - the Latin language, Roman public institutions, and the Roman law. In our opinion, static model of the society - understanding the structure of society as a "condition" of citizens that almost completely corresponds to the modern legal term "civil condition" with the only difference that it applies in relation to each individual equal citizen, was developing in line with jurisprudence as the reception of the Roman law provisions. The organization of a centralized system of authority relations required justice structure complexity, which, in turn, caused the necessity of legislation unification, based on the disparate positions of traditional city law. Hierarchical subordination structure of judicial institutions pushed the final decision-making authorities territorially outside the settlements. The existing identification of persons by "interpersonal recognition" in many cases caused seri- 
ous problems for making competent judgments. The problems created by the absence of written documents proving the civil status of all the participants of the trial, along with the widespread use of "nicknames" in public circulation demanded an immediate solution. In 1589 the king of France, Francis I issued one of the first official documents in which four articles were devoted to the settlement of legal status of citizens. According to the sacred concept of Bishop Lansky Alberoni on the Christian structure of society, "christiana status", from now on in the kingdom three states are fixed: clergy - takes care of the spiritual health of the congregation, chivalry guards it, and the rest of the remaining population is engaged in worldly affairs. Everyone stays in their place in the hierarchy of the earth where God placed them, and this hierarchy reflects the heavenly hierarchy: Distinctus disponitur ordo supernus, Cuius ad exemplar terrenus fertur haberi (The basis of the heavenly order - is inequality, and earthly, as it is said, is created in the image of the heavenly). Ordinance Villers-Cotterets (Ordonnance de Villers-Cotterêts) has obliged all the subjects to use French instead of Latin in the official documents (Фмори, 1999). The static model of the Christian world - state of peace, "status mundi - is one of the main themes of the sacred discourse. For example, according to the teachings of Joachim of Flora, or Calabria (1130-1202) set out in his work Matching Old and New Testaments, history of mankind is a manifestation of the divine revelation. To every face of the Holy Trinity relates its own special stage of revelation, which corresponds to a certain state of the world. "The first state of the world was held in slave service $<<$ servitus status $>>$, second - in filial obedience <<servitus filialis status $>$, and third state $<<$ tertius status in plena spiritus libertate $>-$ is the future, which is in the acquisition of human freedom of the spirit and liberation from worldly cares. The first is the state of slaves, second - sons, third - friends". The concept of Joachim of Floris was in sharp contrast with the official church doctrine. The greatest authority of the time Thomas Aquinas (1225-1274) rejected it, and it has been consistently condemned by three church councils (Семенов, 2003). However, according to Jean d'Alembert, the emergence of society differentiation into three states has been caused by previous historical events. The author believed that the feudal social relations are in many ways a paradoxical result of transfer to the local population of the traditions of "military democracy" of the Germanic tribes who invaded the Roman Empire. "During the conquest, these peoples have preserved customs, habits and inclinations of their homeland, because no nation is changing rapidly their way of thinking and acting. Armies withdrawing from their overpopulated areas were not the armies of mercenaries. These were the associations of volunteers and accomplices of the campaigns undertaken. All associations under the command of their leaders 
were separate armies of any campaign, and everyone fell under the general leader - military leader, elected by common agreement among the leaders of the groups; in a word it was the allied army. The formation of this society required that ownership of conquered areas belonged to all members of the allies and each had its share due to the fact that he helped to win" (Ревуненкова, 1978). According to Lewis Morgan, in such professional military communities the traditions of "military democracy" are immanently caused by Potestarian relations, which are characterized by extreme ideology of valor and courage, based on competitiveness, multilevel ranking achievements through intuitively clear for all members of the military collective pragmatic assessment of the physical, moral, and intellectual qualities of the individual. The full members of the team were considered to be only adult and healthy men trained in weapons handling. Any man who did not have all this complex of skills needed to conduct a war was considered to be an "outcast" and did not have the right to vote. At various times, military democracy existed in almost all nations. Among the ancient Germans the election of leader was accompanied by numerous military ceremonies with a pronounced ideological character. Voting was carried out through concerted shouting and raising weapons in the right hand - acclamation and ended with raising the leader on a shield. Over time, the tradition was preserved - the procedure for electing the king of the Frankish kingdom and the German Empire was largely identical (Морган, 1933). It is believed that over time the Franks have transformed such meetings into the so-called March fields, "champ de mai", the Germans and Scandinavians into tings (scand. "ting", icel. "ping", ger. "Tag"), Anglo-Saxons into "witenagemot". Further specialization of the "military line" - the emergence of aristocracy and legal institutions - is the basis for the second state. The rebirth of military democracy into the urban - a civil way of development, which is caused by the emergence of urban settlements and specialization at industrial and commercial fields, that in turn, served as the basis for the emergence of traditional law of the third generation. Exactly this "communal revolution" (between $10^{\text {th }}$ and $13^{\text {th }}$ century) contributed to finalizing the concept of the three states of the medieval society. At the end of the $12^{\text {th }}$ century the rivalry for power between King Philip IV of France and Pope Boniface VIII grew into a wider conflict. Its apogee was the ban on export from France of gold and silver coins. To make the king's decision legitimate, apart from the constantly operating Royal Council ("Conseil du roi"), a principally new institution in which all three states were represented was convened on 10 April 1302. Its name clearly reflects the finalized static model of society - States-General, "États généraux". The notion of the structure of society as a state of citizens was sufficiently robust and widespread across the Eu- 
ropean territory, which is testified by eloquent official names of class meetings: Estates of Scotland or Thrie Estaitis - Scotland, 1326; Ståndsriksdagen - Sweden, 1435; Staten-Generaal - Netherlands (Duchy of Burgundy), 1464. Nikolai Lazarevsky believed that in the Russian Empire the concept of the three states was borrowed from the European legislation by Catherine II in 1785 and it is mostly reflected in the Charter to the Nobility and Charter on the rights and benefits of cities. In 1832 Russian lawyers, when systematizing uncoordinated legislation, have created the Code of Laws of the Russian Empire. Volume 9 of this edition is called - "Laws on the states". However, many meanings of the word "state" caused more frequent use not only in everyday language but also in the scientific revolution the lexical unit "estates". Nikolai Lazarevsky was proving that using the word "state" would be more correct and accurate: "The concept of estate according to the terminology of the current legislation is very uncertain. In our legislation, this concept is corresponded by the term state - a separate group of subjects that with their legal position are in a certain way different from the rest of the population, and these differences are inherited. Occasionally, however, in law the term estate in this sense is also used". The static model of society is also reflected in works of many researchers from the Holy Roman Empire (Аазаревский, 1890). In 1488 Alsatian monk Johannes Lichtenberger, Frederick III's court astrologer, published in Heidelberg his popular book Prediction (Prognosticatio), having a pronounced encyclopedic nature. The work is entirely devoted to predicting political events and contains a large number of mathematical and geometrical calculations, detailed excursions into history, substantial alchemical information, moral guidance for the nobility, and an extensive apology for astrology. Soon the work was translated from Latin into German and by 1600 it was reprinted 60 times by large print runs. The publication contained a large number of attractive engravings-illustrations, which also contributed to its immense popularity. The notion of the society structure as of a state (Stand) of three states citizen is reflected on a separate engraving and reasoned in details on multiple pages: according to the teachings of Christ, first state pronounces sacred prayer, the second is designed to protect, and third for everyday work (Mentgen, 2005, p. 227). In 1495 between Emperor Maximilian I, the Holy See, and the urban classes of the empire agreement on establishment of Reichstag as the highest representative body of the imperial states (classes) was reached. The Reichstag consisted of three chambers - in the first two the representatives of aristocracy and clergy were sitting, in the third which got the title "Reichsstädtekollegium or Reichsstädterat" - the representatives of cities. Legislative activity of the Reichstag was expressed in publishing of the set of disparate regulations, which became known as the imperial police regulations "Re- 
ichspolizeiordnungen". These documents mainly regulated the activities of the third imperial estate "Reichsständen", unfolding in free "Freie Stadt" and imperial cities "Reichsstadt" and regions falling under their influence, which territorially coincide with the principalities. It is fully consistent with the current understanding of the state, an association (union) of which was the Holy Roman Empire. We can say that such idea of Germany's federal political structure since that distant time has remained to the present day.

Veit Ludwig von Seckendorff among the German authors was one of the first to equate the internal social structure of principalities both as the state of the empire citizens and as a state (Union) of principalities in his book Teutonic princely state (Teutscher Fürstenstaat, 1655). In both this and the other his famous work - Christian state (Der Christenstaat, 1685), the already fully formed reformatory patron absolutist conception of power is well reflected. Secular power was established by God to punish the wicked and protect the pious. Nobody but the German princes can be trusted by God to take care about the subjects of their kingdoms, and that is why they are responsible to the divine authority for the existence of an equitable social order in the Holy Roman Empire of the German Nation. This concern is similar to the father's care of his family. Patron must ensure not only the preservation of peace, well-being, and public order in the territory entrusted to him, but also he must take care of the health, moral, and cultural development of his subjects. Thus, the initiative of public goods' production - economic and cultural self-development of urban citizens (Polizeistädte) formerly owned by the public of the city, gradually submits to the central will, slowly unifying and standardizing.

The functioning of a fairly complex community-city mechanism protecting life, health, property, and public order through complex internal interactions between departments' guilds and parishes, realizing the desire of each individual citizen to well-being through his own participation, is characterized by the leader of Reformation Martin Luther as "guter Polizei". In his work To the Christian Nobility of the German nation on the improvement of Christian state (1520) Luther sets out the idea of a new fair order for independent German states. "There is no other power in Christianity rather than only for improvement. God gave us power not to worsen, but to improve Christianity. In Christianity there must be the following order: each city chooses from a godly community an enlightened citizen, instructs him to take the post of parish priest, and offers the maintenance from the community so that he by preaching and sacraments helps manage the parishioners and the community. The title of the parish priest is ascertained by God and is designed to manage communities by means of the sermon. By this abode the priest should live and have his own terrestrial farming. District courts and 
traditional law should be preferred to imperial common-law. And may it be the will of the Lord to make every region governed by its own short right according to their way of life and occupations as it was before. Extensive detailed laws serve only to encumber people and hamper rather than promote justice. Reasonable secular rulers give the community enough rights to manage the mundane affairs. Is there a rational man among us, who could judge his fellows?". Besides the community affairs within Commandments a Christian should also contribute to the secular authority. Luther writes: "That's why, if you see, one lacks the executioner, the judicial police officer, a judge, lord or Duke, and you think you are capable of doing it, you should require this position, not to make the required power (the government) despised, that it was not weak and did not die. Because the world can not manage without it. We are Christians, and each of us is obliged to help another. We have the power in front of God and the world, leave and allow it in the name of unity. Because Christ says: Where the two will unite on the Earth, I am among them there. If it is the will of God, we from both sides will facilitate this, from both sides the hands with fraternal humbleness will stretch out, and we will approve ourselves not in our power or right; love is more important and necessary than the Roman papacy, in which there is no love, as well as love is possible without the papacy". Municipality of the German people - principal ideal propagated by Reformed Church - contributed not only to the transformation of Germany itself, but Europe as a whole. According to the views of Luther, the structure of communities in apostolic times should serve as a model for a political structure of the new German society. "For the glory of God, in the help to one's neighbor" here is the most full and multilateral religious and moral ideal of a future life in accordance with primary sources of Christianity. And today this expression taken from the public discourse of that distant time can be found in Germany, inscribed on the buildings of the voluntary fire brigade depot. According to Max Weber, Lutheran concept of the Protestant work ethic, which had determined labor zeal and rational organization of work of the most rapidly developing countries such as Holland, England, and the USA, has served as a turning point in the emergence of capitalist enterprises and determined the spirit of the new times (Вебер, 1990, p. 44). But, apart from the traditions of entrepreneurship, Protestant sermon has also laid the foundations of a modern civil society through nurturing in the congregation the culture of government and collaboration. According to Wilhelm Dilthey, Reformation played a fundamental role in shaping the modern German state and European culture, having defined the community as bearer of political organization of social action. "Inner man", the invisibility of the religious process in it, his freedom does not contain a relationship of power and obedience in the eccle- 
siastical a whole: only political alliances enable the organization of social action. The sphere of faith affairs - is the secular society and its arrangement. With this state the total termination of any Church social action is achieved. This is one of the greatest organization ideas ever created by man. Instead of ranks of the three states established by birth, a Christian and secular society appears - an apostolic community of believers and secular traditions in the relations between members of a civil society. Prayers, protection, and labour are performed all together and by each separately only when each is occupied by his own business (Аимьтей, 2000). A peculiar reception of Luther modernist project on transformation of society has become the German political science (Polizeywissenschaft), laid by explorations of von Zeckendorf, initially oriented on common affair of improving national federal state similarly to "economic partnership on shares", which is intended to take care of the increasing population and its well-being.

Of course, our cross-cultural overview of the development dynamics of the concepts of "socium", "politics", "state", and "society" is a rather quick and conditional, but it allows to select between them a partial identity in relation to society as to some aggregate of individuals, united by the common goal of reaching a certain level of satisfying a wide range of needs. Simultaneously, an indication on an action or interaction, their sequence or specified order is present only in the definition of "politics", that in turn, allows to interpret the combination of words "social politics" in an extended foreshortening. Although since the times of the "Iron Curtain" more than twenty years have passed in the former Soviet Union, the lack of information is still felt, which would allow to demythologize stamps and beliefs caused by the previously dominant monopoly of theoretical doctrines. Such inertial attitude is imposed on Western institutions' export expansion, which in turn is accompanied by fragmentary reception of theoretical constructs complicated by linguistic, conceptual, and etymological differences. To resolve this dissonance further, critical analysis of conceptual and categorical framework is needed. We assume that this is why in the former Soviet Union areas most theorists and practitioners of "social politics" understand politics held by the government ("governmental social policy") in the sphere of social insurance - centralized resource allocation from the funds, provided in the state budget for the purpose of leveling the social situation of individuals and groups as compared with the rest of society. Also a set of measures to ensure free (preferential) access to other material and nonmaterial resources, which are administered by the government, including all procedures associated with the production and management of public benefits refers to social policy. Besides government, as the subjects of social policy can serve also supranational entities (in this case we speak of a supranational social policy), 
individual administrative units (local or regional social policy), as well as separate public and commercial organizations (internal social policy).

Hence, as the subjects of state social policy can act only the institutions or organizations that are involved or directly influence the development of the social policies of the government - first of all, these are legislative and executive authorities of all levels, as well as large business well represented in them, and to a lesser degree - trade unions and other civil society organizations. We believe that this view only partly reflects the entire spectrum of relations taking place in the society on a daily basis, artificially limiting the field for analysis and scientific expertise of cause-effect relationships in the area of social problems solution. Social policy can not be just a part of government activities in order to prevent social unrest, it is a complex system of various activities carried out by citizens who are both in hierarchical and also network coalitions aimed at identifying, matching, and satisfying the interests of individuals and social groups. First of all, the subjects of social policy are the individuals whose activities are aimed at achieving prosperity and stability for their families based on affective and emotional links. Formation of social policy is the result of interaction between social subsystems in a form of purposeful activities of individuals, living in a certain territory and being in diverse social connections among which the main are relations concerning resource management in production, distribution, exchange, and consumption caused by the need of maintaining physical life activity. Striving to achieve a certain level of wealth, and, later, preservation of a stable environment in the future is the main motive behind cooperation for the establishment of a social order. Matching variety of spiritual and material needs takes place in the framework of various specialized organizations. Individuals who are in different social structures, in relation to them can act as an object and also as a subject of management. Thus, the government is just a separate subject of social policy, to which the citizens in order to establish social order, delegated the part of their competences, partly to having limited their possible liabilities to perform a set of rules and payments in the form of tax. In turn, development and implementation of the government (state) social policy is always accompanied by the need to establish priorities in determining the most important social problems, requiring urgent solutions, directly pointing out that the centralized redistribution of resources can not be the only satisfactory option to establish social order. At the same time, it is necessary to remember that the use of a centralized way to redistribute the resources is largely caused by the imperfection of market exchange. The existence of such flaws, inherent in these two almost opposite sides of human activities organization, originally predefined by their natural qualities, allows you to emphasize a certain set of social demand, sat- 
isfied by the third alternative method. Intuitively it is clear that this third method is used in parallel with the first two, compensating their shortcomings. Its natural area of distribution is limited by functions carried out by the market or centralized redistribution. Thus, the viability of a third mode of public goods production depends only on the subjects, generating the demand for it, which should at the same time act both as performers and organizers, in other words - to organize by themselves. In this context, self organization should be understood as dynamic processes that, as a result of a cooperative interaction between the elements of one level, lead to streamlining the state owing to internal factors, by forming a more effective structure of higher level, which has new qualities. Organizations created by means of the method described above are usually attributed to the third sector of the modern civil society.

\section{References:}

Barnes, T.D. (1982). The New Empire of Diocletian and Constantine. Cambridge, Mass., and London: Harvard University Press.

Daguet, F. (2007). Principes d'anthropologie politique chez saint Thomas d'Aquin et première leçon du commentaire de la politique d'Aristote. Bulletin Thomiste, 1.

Dowdall, H.C. (1923). The Word «State». Law Quarterly Review, 39. 98-125.

Hannah, A. (1958). The Human Condition. Chicago: University of Chicago Press.

Höffe, O. (2011). Immanuel Kant, zum ewigen Frieden. Berlin: Akademie Verlag.

Liberman, A.A. (2009). Bibliography of English Etymology: Sources and Word List. University of Minnesota Press.

Luhmann, N. (1980). Gesellschaftsstruktur und Semantik: Studien zur Wissenssoziologie der modernen Gesellschaft I. Frankfurt: Suhrkamp.

Mentgen, G. (2005). Astrologie und Öffentlichkeit im Mittelalter. Stuttgart (Monographien zur Geschichte des Mittelalters). 227-235.

Mulgan, R.G. (1974). Aristotle's Doctrine That Man Is a Political Animal, Hermes.

Russell, B. (1928). Sceptical Essays. London: George Allen \& Unwin Ltd.

Simon, H. (1957). A Behavioral Model of Rational Choice, in Models of Man, Social and Rational: Mathematical Essays on Rational Human Behavior in a Social Setting. New York: Wiley.

Wetterau, B. (1994). World History. New York: Henry Holt and company.

Алексеева, Т.А. (2011). «Государственная разумность» (raison d'etat) в политической мысли раннего Модерна. Материалы международной научной конференции «ПоАитика в текстах - тексты в политике: наука истории идей и учений» (к 40-летию кафедры истории социально-политических учений факультета политологии МГУ им. М.В Аомоносова), 28-29 октября 2011 года. Часть первая. Аокцады. Москва: Российская политическая энцикмопедия (РОССПЭН). 
Алигьери, А. (1999). Монархия. Москва: «КАНОН-пресс-Ц»- «Кучково поле».

Бовези, К. (1961). Хрестоматия памятников феодального государства и права стран Европы / пер. Э.И. Аисохиной. Москва: Гос. изА. юр. мит.

Вебер, М. (1990). Протестантская этика и дух капитализма // Вебер М. Избранные произведения / Ю. Н. Аавыдов, сост., реА., послесл., П. П. Гайденко, предисл. Москва: Прогресс.

ВАасов, В.И. (2002). Теория государства и права: учебник Аля высших юридических учебных заведений и факультетов. Ростов-на-Аону: Феникс. 70-75.

Гегель, Г. (2008). Феноменология духа. (Вступ. статья и комментарий Ю. Р. Селиванова). Москва: Академический Проект.

Гоббс, Т. (1991). Аевиафан ими Материя, форма и власть государства церковного и гражАанского // Гоббс Т. Сочинения: В 2 т., Т. 2. Москва: Мысль.

Аильтей, В. (2000). Воззрение на мир и исследование человека со времен Возрождения и Реформации / Академия исследований культуры; пер. с нем. М. И. Аевина. Москва, Иерусалим: Университетская книга, Мосты культуры.

История в Энцикмопедии Аидро и д’Аламбера. (1978). Перевод и примечания Н. В. Ревуненковой. Под общей редакцией А. А. Аюблинской. Аенинград: Наука.

Институциональная архитектоника и Аинамика экономических преобразований. (2008). Под реА. А-ра экон. наук А. А. Гриценко. Киев: Форт.

Кант, И. (1966). ИАея всеобщей истории во всемирно-гражданском плане. Москва: Мысль. Соч. в 6 т., Т. 6. 12-13.

Аазаревский, Н. (1890). Сословия. Энциклопедический словарь Ф. А. Брокгауза и И.А. Ефрона. Санкт - Петербург: Брокгауз-Ефрон. 1890-1907.

Ауман, Н. (2000). Формы помощи в процессе изменения общественных условий / Пер. А.В. Озирченко, А. Н. Малинкина // Социологический журнал, 1/2. 16-35.

Макиавемли, Н. (2009). Рассуждения о первой декаде Тита Аивия / Сочинения исторические и политические: [сборник: перевод с итальянского]. Москва: АСТ.

Морган, А.Г. (1933). Аревнее общество или исследование киний человеческого прогресса от Аикости через варварство к цивилизации. Аенинград: Наука.

Семенов, Ю.И. (2003). Фикософия истории. Общая теория, основные проблемы, идеи и концепции от Аревности до наших дней. Москва: Современные тетради.

Сергунин, А.А. (2010). Суверенитет: эволюция концепта. Москва: Политэкс. Т. 6, 4. $5-22$.

Сироткин, О.С. (2011). Система мироздания как фундаментальная основа единой универсальной кмассификации естественных и гуманитарных наук // Успехи современного естествознания, 2. 74-78.

Скрынников, Р.Г. (1994). Трагедия Новгорода. Москва: ИзА-во им. Сабашниковых.

ФАори, Ж. (1999). ИАеология меча. Предистория рыцарства / Пер. с фр. М. Некрасова. Санкт-Петербург: Иза. Евразия.

Фуко, М. (2011). Безопасность, территория, население: Курс мекций, прочитанных в Колмеж де Франс в 1977-1978 учебном году. пер. с франц. В.Ю. Быстрова и Ар. Санкт-Петербург: Наука. 